\title{
Understanding Digital Natives' Learning Experiences
}

\section{Conhecendo as experiências de aprendizagem de nativos digitais}

Claudio de Paiva Franco*

Universidade Federal do Rio de Janeiro - UFRJ

Rio de Janeiro - Rio de Janeiro / Brasil

ABSTRACT: This paper aims to provide a better understanding of digital natives' perspectives on English learning. The present case study analyzes data from a group of Brazilian learners of English who study at a federal, public high school in Rio de Janeiro, Brazil. Data collection includes: (a) a questionnaire to examine the profile of the participants and (b) learner narratives. This study privileges an interpretive approach based on Complexity Theory in an attempt to understand participants' learning experiences from a more holistic, whole-systems approach. Results indicate that the complex adaptive learning system of digital natives is self-organizing and chaotic. Moreover, the final remarks stress a pressing concern regarding English teaching in Brazil and suggest that the current pedagogical practices no longer serve the needs of the digital generation.

KEYWORDS: digital natives; complexity; English language teaching.

RESUMO: Este trabalho tem por objetivo fornecer uma melhor compreensão das perspectivas de nativos digitais sobre a aprendizagem de inglês. O presente estudo de caso analisa dados de um grupo de aprendizes brasileiros de inglês que estudam em uma escola federal de Ensino Médio, localizada no Rio de Janeiro, Brasil. A coleta de dados é feita por meio de (a) um questionário para traçar o perfil dos participantes, $\mathrm{e}(\mathrm{b})$ as narrativas dos alunos. Este estudo privilegia uma abordagem interpretativa com base na teoria da complexidade, de modo a tentar entender as experiências de aprendizagem dos participantes a partir de uma forma mais holística, de sistemas. Os resultados indicam que o sistema adaptativo complexo de aprendizagem de nativos digitais é auto-organizante e caótico. Além disso, as consideraçōes finais destacam uma preocupação séria com o ensino de inglês no Brasil e sugerem que as atuais práticas pedagógicas já não atendem às necessidades da geração digital.

PALAVRAS-CHAVE: nativos digitais; complexidade; ensino de inglês.

* cpaivafranco@yahoo.com.br 


\section{Digital natives}

Who are digital natives? Do they learn differently? How do they feel about learning in school? Will someone born in a place deprived of the latest technology easily perform multiple digital tasks simultaneously? Will this person still be called a digital native? This paper seeks to provide a tentative explanation for some of these questions.

The pertinent issue at hand is: How many times have you been surprised to see one-year-olds switching on and off the television or intuitively using a digital device without reading its manual? As Palfrey and Gasser (2008) discuss, people from today's generation are 'born digital'. For them, "they were all born after 1980 (...). They all have access to networked digital technologies. And they all have the skills to use those technologies. (Except for the baby but she'll learn soon enough.) (2008, p. 1).'

Digital natives - a term coined by Marc Prensky in 2001 - come from a digitally bombarded world. When referring to the digital generation, Prensky defines them as native speakers of the language of digital technology, that is, they speak "digital" as a first language. As Prensky also suggests, "digital natives' brains are likely physically different as a result of the digital input they received growing up (2001b, p. 1)."

Digital natives seem to present a cerebral architecture better equipped for the digital environment. Above all, their life experiences are molded by experiences with digital technologies. They are immersed in technology, and they use digital tools naturally, without contemplating how they work. Their brains switch spontaneously to the digital world. Digital technology comes naturally to this particular generation - not only to those with access to the latest digital media, but also, surprisingly, to those disadvantaged children, the so-called 'technological have-nots'.

In Understanding the digital generation (JUKES; MCCAIN; CROCKETT, 2010), Jukes describes a picture he took in the 300-year-old Arab market in Singapore, where locals say that, other than electricity and cars, the place is not so very different than it was three centuries ago. It is a picture of "an 11-year-old girl who was sitting on a bolt of cloth patiently waiting while her mother bartered for fabric. In her hand was a palm-sized wireless device she was using to surf the Internet (JUKES et al., 2010, p. 14)."

Based on a comprehensive review of the literature (GASSER; CORTESI; MALIK; LEE, 2012; JUKES; MCCAIN; CROCKETT, 2010; MILLER, 2011; PALFREY; GASSER, 2008; PRENSKY, 2001a, 2001b, 
2006, 2010, 2012), and my own observations as a teacher, the following characteristics can be identified among digital natives:

- They live in the world of computers and video games;

- They are constantly connected to the online world;

- They have the capacity to use digital technology transparently;

- They express themselves in ways mediated by digital technologies (primarily mediators of human-to-human connections);

- They have plenty of friends in social networking sites (including people who they have never met in person);

- They feel comfortable in online spaces;

- They rely on online spaces to search for all the information they need (they learn through browsing);

- They have a tendency to attend to several things at once - multitasking;

- They receive and process information at a rapid pace;

- They share photos and videos with their friends all over the world.

According to Jukes, McCain, and Crockett: "the digital generation has adopted a mindset of rapid-fire trial-and-error learning. They're not afraid of making mistakes because they learn more quickly that way (2010, p. 16)." As Prensky points out, digital natives are learning differently. He argues that learning only occurs in its purest form when natives truly wish to learn about something, such as hobbies, vacations, or games. However, they "are very much aware that if they want to learn something (usually for their own purpose), the tools online are available for them to do it on their own (PRENSKY, 2012, p. 96)."

The term 'digital native' is used in this study to refer to learners who were not only born in a world surrounded by digital technology, but who also make use of digital media as an integral part of their lives. Under no circumstances do I assume that they are either superior or inferior to people from the previous generation, the "digital immigrants", which refers to those born before the digital technology boom.

To reinforce this point, Koutropoulos (2011) calls our attention to the stereotypes of the digital native that common sense often produces, inviting us to rethink such assumptions. He argues that an artificial dichotomy is created when, depending on the cultural context, natives are placed in a 
privileged or non-privileged position. He then suggests we move away from labeling today's generation as 'digital', 'net', or 'Google', as these terms do not describe them properly. His main concern is that students, believing they are completely fluent in digital technology as a result of persistent feedback affirming their knowledge, will end up losing opportunities to learn new information to which they have not yet been exposed. As Prensky also pinpoints in his later work: “... by virtue of being born in the digital age, our students are digital natives by definition, but that doesn't mean that they were ever taught everything (or anything, in some cases) about computers or other technologies, or that all of them learned on their own (2010, p. 64)."

Before analyzing digital natives' views on their learning experiences through the lens of complexity, it is necessary to define underlying principles of Complexity Theory (CT) and the characteristics of complex systems. These will be described in the following section.

\section{Complexity Theory}

Complexity Science represents an emergent realm of complexity thinking. Moreover, it represents a body of multidisciplinary knowledge, a whole-systems approach that is an alternative to the traditional mechanistic paradigm, the kind of linear, reductionist view of the world that has dominated science since the era of Newton. Insights from complex systems research have increasingly provided a new understanding of emerging complex phenomena.

Johnson describes Complexity Science as the "study of the phenomena which emerge from a collection of interacting objects (2007, p. 3).” In CT, these objects are often called 'elements' or 'agents', the latter referring to humans and other animate beings. He complements this definition by claiming that the collection of objects is able to "self-organize itself in such a way that the phenomenon appears all by itself - as if by magic (Ibid., p. 5)." In addition, he argues that "it is extremely difficult, if not impossible, to deduce the nature of these emergent phenomena based solely on the properties of an individual object" (Ibid., p. 10).

To be clear, it therefore becomes imperative to define a system. A broad definition of the term "system" is "a regularly interacting or interdependent group of items forming a unified whole." ${ }^{1}$ In other words, a system is produced by a collection of parts that interact to form an integrated whole.

\footnotetext{
${ }^{1}$ Available at: <http://www.merriam-webster.com/dictionary/system>. Accessed in: July 2012.
} 
A consensually accepted definition of complex systems, proposed by the New England Complex Systems Institute (NECSI), is "a new field of science studying how parts of a system give rise to the collective behaviors of the system, and how the system interacts with its environment." 2 As Waldrop points out, the term 'complex' adds the idea of several independent agents "interacting with each other in a great many ways (1992, p. 11)."

For Larsen-Freeman and Cameron (2008), a complex system contains different types of elements, usually in large numbers, which connect and interact in different and changing ways. These authors believe that change is likely to be the most distinguishing feature of complex systems, as they are in a constant flow.

\subsection{Features of complex systems}

Larsen-Freeman discusses the features of these systems in her seminal paper Chaos/Complexity Science and Second Language Acquisition, published in 1997. The systems are characterized (in varying degrees) as: "dynamic, complex, nonlinear, chaotic, unpredictable, sensitive to initial conditions, open, self-organizing, feedback sensitive, and adaptive (LARSEN-FREEMAN, 1997, p. 142)."

Dynamic systems are those that change over time. Larsen-Freeman and Cameron (2008) highlight that not only do the component elements and agents change over time, but they also behave in such a way that components interact with each other. Changes can be discrete, occurring in steps or stages, or continuous and unending. Harshbarger argues that "the main feature that characterizes complex systems is the dynamic interaction of various elements of the system over time such that the results of these interactions are not entirely predictable or proportional (2007, p.2)." He furthers this point by claiming: "it is an illusion to speak of isolating a single interaction between two particles and to claim that the interaction can go backward in time" (BRIGGS; PEAT, 1989, p. 148).

Another feature of complex systems is nonlinearity, that is, the nature of connections and interactions among elements and agents change over time in a way that is not proportional to input. In other words, the components in a complex system are not independent, and relations among them do not remain static. By contrast, in linear systems, interactions between elements

${ }^{2}$ Available at: <http://necsi.edu/guide/study.html>. Accessed in: July 2012. 
and agents are static, and change in the system is completely constant and predictable.

Larsen-Freeman refers to complex systems as "the period of complete randomness that complex nonlinear systems enter into irregularity and unpredictability (1997, p. 143)." It is predictable that randomness will occur; however, it is unpredictable to determine when that specific moment will occur.

The unpredictable behavior of complex systems is attributed to their extreme sensitivity to initial conditions. A minor shift in initial conditions can lead to a large or catastrophic change in the system.

These complex systems are also considered to be open systems, meaning that they are in constant contact with the environment around them and can be directly influenced by it. In other words, these systems exchange energy or matter with their immediate surroundings. A system can be defined as "open" when it is far from reaching equilibrium ('steady state'), as Davis and Sumara claim: "a stable equilibrium implies death for a complex system (2006, p. 6)." As Johnson points out: "Much more common are systems that in some way are in contact with the outside world. In fact, the only truly closed system is the Universe as a whole (2007, p. 16)."

By constrast, Dempster refers to self-organizing systems as "systems that appear to organize themselves without external direction, manipulation, or control (1998, p. 42)." A self-organizing system, in the words of Wolf and Holvoet, "is expected to cope with (...) change and to maintain its organisation autonomously. In other words, a self-generated, adaptable behaviour is needed $(2005$, p.8)." In addition, they argue that "a change in the environment may in?uence the same system to generate a di?erent task, without any change in the behavioural characteristics of its constituents" (Ibid., p. 8). Wolf and Holvoet (2005) argue that self-organization and emergence should not be described as synonymic, as they each emphasize different characteristics of a system's behavior. Furthermore, they defend that:

Self-organisation requires the evolution towards a certain attractor in state space (i.e. towards a certain organised behaviour). There are di?erent kinds of attractors, from a point attractor that allows only one behaviour, a limit cycle that allows periodic behaviour, towards a chaotic attractor that allows a very large variety of behaviours. To be adaptable, the system needs to make a selection between behaviours and at the same time consider a variety of behaviours. Too much variety, like the chaotic attractor, makes the system uncontrollable (WOLF; HOLVOET, 2005, p. 8). 
Adaptation in complex systems is the process by which a system adjusts itself in response to changes in its environment. In the words of Davis and Sumara: "complex systems embody their histories - they learn - and are thus better described in terms of Darwinian evolution than Newtonian mechanics (2006, p.6)." Systems that work in this way are called 'complex adaptive systems' (LARSEN-FREEMAN; CAMERON, 2008, p. 33). An example of a complex adaptive system is the school. As Larsen-Freeman and Cameron argue, the school "is clearly an open system, and may also be a non-equilibrium dissipative structure, in which the order or dynamic stability is, hopefully, the experiencing by learners of meaningful and life-affirming education" (2008, p. 33). This scenario includes certain components, including teachers, students, a curriculum, and a learning environment; additionally, external factors may influence these components and interactions. If an education system can adapt to the influences of changing external factors, it will maintain the dynamic stability and overall identity of effective learning. Furthermore, these systems can be considered adaptive in the sense that, rather than merely responding passively to events, "they actively try to turn whatever happens to their advantage (WALDROP, 1992, p. 11)."

\section{Methodology}

This section describes the research methodology, the study's participants, the research instruments, and the procedures for data collection and data analysis.

This study adopts a qualitative case study methodology. As opposed to quantitative research, also known as positivist-oriented research, the current study privileges an interpretive approach and uses learner narratives as its main research instrument. This choice is based on the attempt to reach better understandings of participants' perspectives by being sensitive to their learning experiences. According to Hinchman and Hinchman (1997), narratives represent ways of knowing and communicating through stories. According to Bell (2002), narratives are stories told in a conscious fashion and offer subsidies for the researcher to understand learners' experiences.

Since this research intends to study complex phenomena within their respective contexts, data analysis is conducted by interpreting narratives through the lens of CT. Constructs of complex systems are used to describe a group of Brazilian learners of English as digital natives and to analyze their views on learning. In so doing, this research intends to deconstruct a more linear 
and reductionist perspective on learning. Complexity allows the teacherresearcher to take into account diverse sensibilities and the multiple sides of a story to understand the underlying subjectivity in learners' narratives, which contributes to higher degrees of reflection and enriches data analysis.

Davis and Sumara, regarding this particular view of complexity in education, argue:

Complexity thinking helps us actually take on the work of trying to understand things while we are part of the things we are trying to understand. It foregrounds that we can never develop an objective appreciation of something of which we are part. Complexity suggests that rather than standing back from the world, we must get involved (and acknowledge our implication/complicity) in the unfolding of the cosmos (2006, p. 16).

These authors also highlight what it means to reject "an uncritical - and, at times, an unjustified - faith in the analytic method, its mechanical and statistical tools, and other features from much of educational research throughout the $20^{\text {th }}$ century" (DAVIS; SUMARA, 2006, p. 25).

The 37 participants in this study are high school students at a federal, public school located in Rio de Janeiro, Brazil. In accordance with a public school schedule, students attend class Monday through Saturday. Each school day there are six separate class periods of 45 minutes each. Students attend three English classes per week, distributed in two days. Regarding English teaching, reading is the most developed of the four skills in the classroom.

All participants were born after 1993, with an average age of 16 . When the data was collected in 2011, the participants were second-year high school students from two separate groups: one from the morning school session and one from the afternoon session. All participants were in favor of taking part in the research and signed an official letter of consent.

It is important to note that the research context described in the current section refers to the educational institution where participants studied at the time of data collection. However, this does not correspond to the richness of learning environments described in the learner narratives. As they were invited to narrate their memories as English learners starting from the moment they first had contact with the language, they have also described other educational settings, such as elementary school and private English courses.

The study relied on two research instruments: (a) a questionnaire to examine the profile of the participants and (b) learners' narratives. 
The participants were first invited to answer an online questionnaire with open and closed questions about their personal details, as well as information on Internet access and preferences. Thirty-one participants responded $(83 \%)$ to the online questionnaire.

All participants have stable Internet access and $94 \%$ have a computer at home with broadband connection. Most participants (77\%) describe themselves as being online daily, while others are online from three to six times a week. Therefore, they are all considered digital natives, that is, they were born in a world surrounded by digital technology and make use of digital media as part of their daily lives.

The questionnaire also shows that almost all participants frequently multitask, attending to several things at once. Only one participant reported performing one task at a time, whereas 30 participants (94\%) perform between two and seven different tasks simultaneously. The tasks they normally perform on the Internet are shown in the following figure.

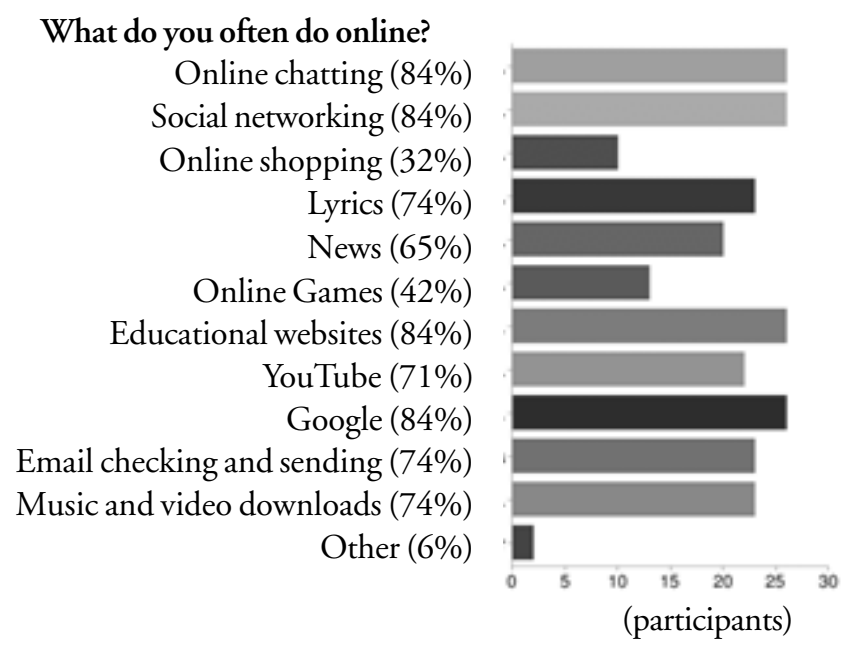

FIGURA 1: Online tasks often performed by the group of digital natives

After answering the questionnaire, participants were invited to write, in Portuguese, a narrative about their past experiences as learners of English. Twenty-three participants (62\%) shared their narratives. However, due to the space limitation of this paper, and to highlight the relations between participants' perspectives on learning and the use of digital devices and resources, excerpts of only three narratives are presented in the following section. The excerpts were selected for their descriptions of recurring events 
and perspectives shared in nearly all learner narratives. These students are no exception to the rule, as they do not correspond to single events or views of one or two learners from the compilation of narratives.

\section{Results and Discussion}

This section reports on and discusses the case study's results. To reemphasize the main point of this study, which is to provide a better understanding of digital natives' perspectives on English learning, key features of complex systems are used to analyze data.

All narratives were written in Portuguese but have been translated into English without changing their original meaning. Regarding page formatting, images, different font sizes, and colors were discarded so as to facilitate reading. Additionally, the three excerpts are accompanied by a fictional participant name.

\section{NARRATIVE EXCERPT 1:}

(...) My first contact with English was through video games ... Well, at least that's my opinion, but my family keeps on saying that I learned English in elementary school, but, quite frankly, I don't think so ... I just learned loose words and I never knew how to form sentences, unless the ones that were already presented like 'What's your name?' So, I just think I began to have a better notion of English when I started playing role-playing games ... Back then I didn't have a large vocabulary of English, so I played role-playing games with a dictionary by my side, always looking up the words I didn't know... It was only when I learned how to infer meaning from context with my father that I gained greater independence from the dictionary ... I'd say it was what made me learn English more efficiently, even compared to what I've learned at the school or at the course I've taken. (...) (Luke)

NARRATIVE EXCERPT 2:

Ever since my first year in elementary school, English was one of the subjects I had at school, but as I always had to memorize things, I never gave much attention to it. When I was 10 or 11 years old, my parents forced me to take English classes at a course, based on the argument that it would be important for my academic future and blah blah blah. I HATED the course, and I always found it nonsense to ??learn a language I would never use in my daily life. Not to mention the fact that the teacher treated me like a stupid kid every time she began to teach ridiculous things like ' $\mathrm{My}$ name is ...'. Then, for some years, I would spend two hours, twice a week, hating the fact that I attended English classes and wouldn't learn a thing!

It was only in 2007 that with the appearance of a new singer, Katy Perry, and the release of her controversial song called 'I Kissed a Girl' that I started to use the Internet to search lyrics (at that time I started to put up with the course-I neither liked nor disliked it). And it was when I realized that I had learned, and I could really understand the lyrics! (...) (Anne) 
NARRATIVE EXCERPT 3:

(...) When I was younger I could not take an English course because of financial difficulties and also because none of them were close to my house. However, since English in elementary school was only based on the verb "to be" and the vocabulary taught was very basic, I always ended up doing well on tests. I always considered the assessments too easy. (...)

Because there were no digital devices in my old school, two great allies for me to study English were music and the Internet. (...) At that moment I resorted to websites that provide the original lyrics of songs in English and their translation into Portuguese like 'Vagalume' and 'Terra'. It enriched my vocabulary and helped me improve my pronunciation as I tried to sing along while I read the original lyrics comparing to the translations. Although those sites don't have very reliable content, and there are many mistakes in the lyrics, they are the easiest way for anyone who at least wants to understand the general idea of a song." (Louise)

\subsection{Participants' views on teaching}

The three participants (Luke, Anne, and Louise) share similar learning experiences and feelings towards English teaching. Learners' memories about English teaching in elementary school is described as something negative, as exemplified in the way they report the pedagogical practices encountered at an early age. From their perspectives, employed pedagogical practices focused on teaching: a) grammar ("only based on the verb 'to be"); b) decontextualized vocabulary ("Ijust learned loose words", "I never knew how to form sentences, unless the ones that were already presented like 'What's your name?"); and c) memorization of structures and expressions ("as I always had to memorize things").

When the participants reported their memories about elementary school, they did so in a negative tone, very much aware that their school did not cater to their needs. As they report, they were offered unsatisfactory: a) teaching ("my family keeps on saying that I learned English in elementary school, but, quite frankly, I don't think so", "I never gave much attention to it"); or b) infrastructure ("there were no digital devices in my old school").

In CT, the unsatisfactory pedagogy practices are seen as strange or chaotic attractors in the system (as described in the previous section).

\subsection{Participants' views on learning}

Luke, Anne, and Louise share the same opinion on what factors are important in effective English learning. With regards to effective English learning, they cite the importance of the following: a) use the language for 
communication ("I always found it nonsense to ??learn a language I would never use in my daily life"); b) have a wide range of vocabulary ("always looking up the words I didn't know", "It enriched my vocabulary"); c) understand at least the main idea of a text ("It was only when I learned how to infer meaning from context with my father that I gained greater independence from the dictionary", "I could really understand the lyrics?", "the easiest way for anyone who at least wants to understand the general idea of a song"); and d) know the pronunciation of words ("helped me improve my pronunciation as I tried to sing along"). From their point of view, the aforementioned items ought to be taught prior to the current pedagogical practices (focus on the teaching of grammar, decontextualized vocabulary, and memorization of structures and expressions).

The digital natives Luke, Anne, and Louise shared interesting learning experiences with the use of digital tools. Anne and Louise, for instance, shared the same motivation towards searching on the Web to find what they want on their own ("My first contact with English was through video games", "I just think I began to have a better notion of English when I started playing role-playing games", "I started to use the Internet to search lyrics", "I resorted to websites that provide the original lyrics of songs in English and their translation into Portuguese")

\subsection{Learning as a chaotic and self-organizing system}

Analyzing the three narrative excerpts from a CT perspective exemplifies the notion that learning a foreign language, like most complex dynamic systems, is adaptive (PAIVA, 2009). The narrative samples clearly show that the interactions among the agents of the learning system (e.g. students, teachers) both changed over time and were influenced by external factors (e.g. unsatisfactory teaching and infrastructure).

However, before jumping to any further conclusions, one must consider the fundamental nature of such learners: they are digital natives. The fact that learners are constantly immersed in technology makes it easier for them to look for online alternatives to compensate for their unsuccessful learning experiences. Irrespective of whether or not they are on the Internet for explicitly educational purposes, this environment seems to offer favorable learning conditions for them. The English learner may have a greater tendency to be autonomous and thus look for digital tools to enhance their learning, or, as a response to disengagement in a learning activity, they may find it necessary to use the Internet as a source to find the solution to a problem in a given task. The latter possibility often occurs when learners need to understand a piece 
of information in the foreign language, often by means of a search engine, specific website, online translator, or online bilingual dictionary.

After interpreting the 23 narratives of the digital natives in this research, it can be concluded that this complex adaptive system is self-organizing and chaotic. As the literature review shows, self-organization requires the evolution towards a certain attractor. In the current study, the unsatisfactory pedagogical practices reported by learners represent chaotic attractors, and they have triggered a self-organizing behavior of the learning system. It is possible to identify that an autonomous agent (student) self-organizes in a way that the system offers conditions for its survival. Despite the teaching practices that did not serve learners' needs, they were still able to seek alternative solutions and have a favorable attitude towards the English language. Had it not been for the 'digital' nature of the learners, they might not have spontaneously resorted to digital alternatives (self-organization) and hold a positive attitude towards learning English. After all, finding information on the Web is the most convenient way for digital natives, who constantly use multitasking, to produce a positive attitude towards learning.

Regarding the chaos in the learning system, this behavior is directly connected to sensitivity to initial conditions. A minor shift in the initial experiences each participant encountered with the English language might have caused the system to react in unpredictable ways. Luke serves as an illustrative example of this. The fact that he enjoyed playing video games allowed him to be in contact with English and to develop an autonomous attitude by consulting the dictionary to understand the meaning of unknown words (" $I$ played role-playing games with a dictionary by my side, always looking up the words I didn't know"). Furthermore, his father played an important part in his learning, as he helped Luke to develop a key learning strategy whenever he came across unknown words "It was only when I learned how to infer meaning from context with my father that I gained greater independence from the dictionary"). No one can accurately predict what would have happened if he had not been a role-playing game enthusiast at an early age or if his father figure had not interfered positively in his learning.

Another example of change over time is the shift in the learner's attitude towards the language. For example, Anne used to hate taking English classes ("I never gave much attention to it", "I HATED the course", "hating the fact that I attended English classes and wouldn't learn a thing"), but at some point she began to feel differently, and in a way that is not proportional to the input ("at that time I started to put up with the course"). 


\section{Final remarks}

The results presented in this case study address only a few key issues concerning Brazilian learners' views on teaching and learning English as a foreign language. The three narrative excerpts presented here are simply a small sample of the richness of stories shared about learners' experiences. Some narratives are longer than three full pages and depict detailed memories, whereas others are shorter but contain a wide range of visual elements. Each narrative is unique and portrays the particular experiences of an individual. Some narratives go beyond the mere descriptions of learning moments and end up revealing the participant's expectations, beliefs, wishes, anxieties, frustrations, and fears about language learning.

Compared to learners from previous generations, today's digital native learners tend to have a different perception of what they are offered at school. Surrounded by a web-enhanced environment offering a wide range of learning possibilities, they lack these affordances when they are in school. While it is true that they miss out on these digital concerns in the classrooms, it is far more pressing of a concern that they miss the proper pedagogy aligned with their expectations and needs (MICCOLI, 2007a, 2007b). This pedagogy ought to be more directly focused on aiding learners to retrieve information and develop the skills needed to analyze information critically.

When digital natives use digital technology, it is often intended to attain a specific and immediate goal that they themselves know they can reach on their own. For instance, they search on the Web to understand unknown words, complicated game instructions, fuzzy Internet pages, interesting yet unclear lyrics, etc. Contrary to this, the current teaching practices do not seem to provide a real purpose to learning a foreign language, as reported by participants in this research. This dissatisfaction and, at times, boredom are often expressed when they talk about attending classes and spending long hours in school. As Prensky emphasizes: "unless we change how things are taught and what is taught, in all of our classrooms, we won't be able to provide an education that has our kids fighting to be in school rather than one that effectively pushes one-third to one-half of them out (2012, p. 15)."

To be clear, it is not the intent this study to use its findings (based only on three narrative excerpts) to make broad over-generalizations or to draw any conclusions about English instruction in Brazil. However, I believe that the narrative samples shown herein are fractals that depict a larger picture of the teaching policies and beliefs in our country and their implications for learning. 
The recurrent obsolete pedagogical practices reported by learners stand to reveal a stable pattern of how English is viewed and taught in Brazil.

\section{References}

BELL, J. S. Narrative inquiry: more than just telling stories. TESOL Quartely, v. 36, n. 2, p. 207-212, 2002.

BRIGGS, J.; PEAT, D. Turbulent mirror: an illustrated guide to chaos theory and the science of wholeness. New York: Harper and Row, 1989.

DAVIS, B.; SUMARA, D. Complexity and education: inquiries into learning, teaching and research. Mahwah: Lawrence Erlbaum Associates, 2006.

DEMPSTER, M. A self-organising systems perspective on planning for sustainability. Master's thesis, University of Waterloo, School of Urban and Regional Planning, 1998. Available at: <http://www.bethd.ca/pubs/mesthe.pdf>. Acessed in: July 30, 2012

GASSER, U.; CORTESI, S.; MALIK, M.; LEE, A. Youth and digital media: From credibility to information quality. Berkman Center for Internet \& Society, 2012. Available at: <http://ssrn.com/abstract=2005272>. Acessed in: July 30, 2012. HARSHBARGER, B. Chaos, Complexity and Language Learning. Language Research Bulletin, v. 22, ICU, Tokyo, 2007. Available at: <http://web.icu.ac.jp/ lrb/vol_22/Harshbarger\%20LRB\%20V22.pdf> Acessed in: July 30, 2012.

HINCHMAN, L. P.; HINCHMAN, S. K. Introduction: Toward a definition of narrative. In: HINCHMAN, L. P.; HINCHMAN, S. K. (Ed.). Memory, identity, community: The idea of narrative in the human sciences. Albany, NY: State University of New York Press, 1997. p. xiii-xxxii.

JOHNSON, N. Simply complexity: a clear guide to complexity theory. Oxford: Oneworld, 2007.

JUKES, I.; MCCAIN, T.; CROCKETT, L. Understanding the digital generation: teaching and learning in the new digital landscape. London: Corwin, 2010.

KOUTROPOULOS, A. Digital Natives: Ten Years After. MERLOT Journal of Online Learning and Teaching, v. 7, n. 4, 2011. Available at: <http:// jolt.merlot.org/vol7no4/koutropoulos_1211.htm>. Acessed in: July 30, 2012. LARSEN-FREEMAN, D.; CAMERON, L. Complex systems and applied linguistics. Oxford: Oxford University Press, 2008.

LARSEN-FREEMAN, D. Chaos/complexity science and second language acquisition. Applied Linguistics. Oxford: Oxford University Press, v. 18, n. 2, p.141-165, 1997. 
MICCOLI, L. Experiência de professores no ensino de língua inglesa: uma categorização com implicações para o ensino e a pesquisa. Linguagem \& Ensino (UCPel), v. 10, p. 47-86, 2007a. Available at: <http://www.rle.ucpel.tche.br/ index.php/rle/article/view/155/122>. Acessed in: July 30, 2012.

MICCOLI, L. Experiência de estudantes em processo de aprendizagem de língua inglesa: por mais transparência. Revista de Estudos da Linguagem, v. 15, p. 197-224, 2007b. Available at: <http://relin.letras.ufmg.br/revista/upload/11-LauraMiccoli.pdf>. Acessed in: July 30, 2012.

MILLER, Vincent. Understanding digital culture. London: SAGE Publications, 2011. PAIVA, V. L. M. O. Caos, Complexidade e aquisição de segunda língua. In: PAIVA, V. L. M. O.; NASCIMENTO, M. (Org.). Sistemas adaptativos complexos: lingua(gem) e aprendizagem. Belo Horizonte: Faculdade de Letras/FAPEMIG, 2009. p. 187-203. Available at: <http://www.veramenezes.com/caos.pdf>. Acessed in: July 30, 2012. PALFREY, J.; GASSER, U. Born digital: understanding the first generation of digital natives. New York: Basic Books, 2008.

PRENKSY, M. From digital natives to digital wisdom: hopeful essays for $21^{\text {st }}$ century learning. London: Corwin, 2012.

PRENKSY, M. Teaching digital natives: partnering for real learning. London: Corwin, 2010.

PRENKSY, M. Don't bother me, Mom, I'm learning!: how computer and video games are preparing your kids for 21 st century success and how you can help! St. Paul: Paragon House, 2006.

PRENSKY, M. Digital Natives, Digital Immigrants. On the Horizon, v. 9, n. 5, p. 1-6, 2001a. Available at: <http://www.marcprensky.com/writing/prensky\% 20-\%20digital\%20natives, \%20digital\%20immigrants $\% 20-\% 20$ part 1 .pdf $>$. Acessed in: July 30, 2012.

PRENSKY, M. Digital Natives, Digital Immigrants. On the Horizon, v. 9, n. 6, p. 1-6, 2001b. Available at: <http://www.marcprensky.com/writing/Prensky\%20\%20Digital\%20Natives, \%20Digital\%20Immigrants\%20-\%20Part2.pdf>. Acessed in: July 30, 2012.

WALDROP, M. Complexity: the emerging science at the edge of order and chaos. New York: Simon \& Schuster, 1992.

WOLF, T.; HOLVOET, T. Emergence versus self-organisation: different concepts but promising when combined. In: BRUECKNER, S. at al. (Ed.). ESOA 2004, LNCS 3464. Berlin: Springer-Verlag, 2005. p. 1-15.

Recebido em 31/08/2012. Aprovado em 9/11/2012. 